\title{
Let Me Tell You: Experiences with Silent Books in a Framework of Early Literacy
}

\author{
Elena Guichot-Muñoz ${ }^{1}$, Giulia De Sarlo², Elena Ledesma-Gobea ${ }^{3}$
}

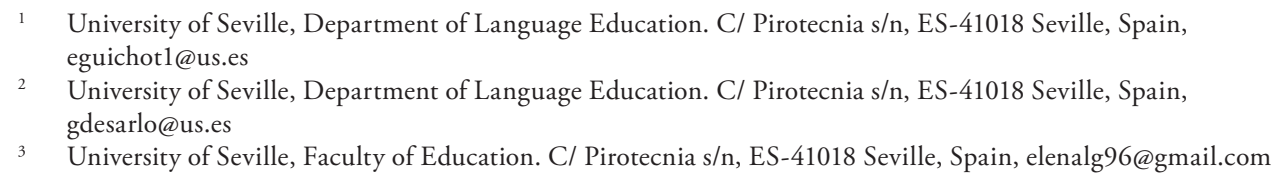

\begin{abstract}
This paper focuses on an experiment with Silent Books with 27 Spanish kindergarten children. Through a qualitative ethnographic methodology based on a multimodal analysis, we study the response to the self-managed reading of Silent Books given by a class group and, specifically, by five students, both in the classroom and at home. The analysis of the results highlights a drastic increase in the motivation towards books and the activation of a series of cognitive precursors.
\end{abstract}

Keywords: early childhood, literacy, silent books, self-managed reading, qualitative methodology.

\section{Introduction}

The aim of this article is to propose a radical change of perspective about literary mediation in early childhood. Analysing an intervention carried out in a nursery school in the South of Spain, we will observe what happens when children are given the possibility of being literature mediators for their peers and their attachment figures. In order to understand the context of this study, it is necessary to recall Bauman's concept of liquid modernity (Bauman, 2003), that focuses on the uncertainty and constant volatility experimented by nowadays societies. If seen from the literacy point of view, this implies a continuous multimodal experience for every subject, which means dissolution of the (unalterable) formal limitations that used to circumscribe the study of discourse. At the present time, discourse can be and is approached through a multiple and varied way, with 
a tendency to revise the immaterial substrate of discourse (Burnett et al., 2014) and its vernacular aspects, so relevant now that spontaneous, non-formal digital communication is taken into account (Area \& Pessoa, 2012). The concept of literacy, from this point of view, opens to a broader sense, since it gets inserted in practices where subjects "decode" messages in order to extract information from them and thus be able to form their own knowledge (Area, Gutiérrez \& Vidal, 2012). A clear example of it is the change occurred in recent literary literacy (Sanjuan, 2013), which evolved from "literate culture", based on paper writing, to "cyberliterature," a space where other types of hypertext languages find a room (Vivas \& Martos, 2013).

At this point, the school and the university can play an essential role. Obviously, this new interdisciplinary perspective emphasizes the relationship between culture and democracy, opening up to a plurality inspired by a new way of conceiving the world (Bauman, 2003). For these reasons, in this article the main research question is: based on this new social reality, what role does literature play in early literacy? If children's literature is understood as a mirror for society, what "literature" can reflect our liquid modernity? Does this model of society fit into books as objects?

As Neuman and Dickinson noted already in 2003, "the understanding that literacy development begins long before children start formal instruction, is now largely taken for granted" (p. 3).

For several decades early literacy has been settling as one of the most fertile areas of research on the development of language skills in early childhood. Already in the 1930s, in his famous Prehistory of the Development of Written Language, Vigotsky claimed that:

The development of written language belongs to the first, most obvious line of cultural development because it is connected with the mastery of an external system of means developed and created in the process of cultural development of humanity. However, for the external system of means to become a mental function of the child himself, a special form of his behavior, for the written language of humanity to become the written language of the child, complex processes of development are required (p. 133).

However, only in recent years increasingly precise scientific frameworks for promoting productive early literacy in the new generations have been developed. Some of them vary from language to language (Balbi et al., 2018). However, as Balbi recalls, "learning to read involves universal components of all the world's writing systems". Following the National Reading Panel Report (2000), development of phonological awareness, alphabetic principle, verbal fluency, vocabulary extension, and oral comprehension would then be the four cognitive precursors necessary and fundamental to lay the foundations for a correct literacy process at an early age:

Along these lines, there seems to be no doubt that the five critical components proposed by the NRP (2000) represent central aspects, which must be 
present in any intervention in literacy (at least in alphabetic orthographies)

(Balbi et al., 2018, 33).

It is true that the key to early literacy most recent research lies in the inclusion and analysis of non-traditional reading materials, from advertising billboards to social network memes. But it is also undeniable that the role of reading in the development of these precursors remains a fundamental factor. In other words: a child who grows up in a house without books is also able to develop his own literacy process, through direct and frequent contact with other types of reading materials; but there is no doubt that children who grow up in a house where their caregivers read, and even more so, in a house where their caregivers read them, will develop their literacy in perhaps a more traditional, but probably more complete way (Moreno, 2013; Solé, 2009). In fact:

the paradigm known as emergent or early literacy (Clay, 1993) (...) does not consider schools as the first context of children's literacy. From this paradigm, the idea of the influence of the family environment and, more specifically, of parents' interactions with their children begins to be defended (Acosta, Moreno \& Axpe, 2014, 44).

Since we are talking about pre-readers, it is usually taken for granted that contact with books will involve mediated reading: there will be an adult (father, mother, caregiver) to conduct the child in the first steps towards the mastery of reading and writing, through contact with printed material. This mediating action is not only given by the need for an interpretation of the code by those who already dominate it, but also by the affective component necessary to bring the child closer to the world of the written word (Ehret \& Leander, 2018). As Quintanal underlines, the so-called "lap reading" builds an experience in which the book is a pretext and a very special motive for the relationship:

We will then define lap reading as the noble, simple and affectionate act of reading recreation that takes place between the child and the adult. It is, therefore, an intense experience in which the act of reading is interpreted in a playful way, to merge into the affective relationship generating shared experiences and feelings (Quintanal, 1999).

The moment of reading in which an adult reads to a baby should not be seen as a plain entertainment activity since to a greater extent it is also an action of affective exchange and trust. The participants of the reading "travel" through their imagination, know new things and identify themselves with situations and/or characters that were perhaps unknown until that moment: "We will live in the imagination the way in which he interprets the facts, the forms, the contents: it does not matter if these respond to the daily reality, or are submitted to the strict rules of real existence" (Quintanal, 1999).

As Durán notes, the accompaniment of an adult is essential for a child to understand the difference between what is strictly real and what is imaginary: "When children look 
at images and begin to identify them, they carry out a much more elaborate mental activity, since they are not in front of a real object, but in front of its representation" (Durán, 2002). The idea is to understand narration as an activity of discourse that is self-managed beyond language (Haquin, Cornejo \& Arancibia, 2016). This identification of each of those things that the adult points out and must name again and again is a step towards a discovery that must be shared: it must be perceived as a challenge achieved together. Quintanal (1999) states that adults should be aware of their role as mediators in the act of lap reading. "...because their work is actually to complement the pedagogical action of the book through stimulus: pointing out images, signifying forms, asking curiosities, encouraging search and inquiry, locating, creating and recreating, identifying and knowing, figuring and imagining" (Quintanal, 1999). It could be said that lap reading is accompanying the youngest children into a new world that they must decode themselves, until they are autonomous enough to release our hand and begin to investigate autonomously and through desire, not an obligation.

But what happens if the message to be decoded is not written, but iconographic? What happens if what we have to "read" is an image instead of a succession of graphemes? During the first months of life, the adult also helps the future reader to decode images - to interpret them and put them in relation to the real objects that surround them. For this reason, very soon and well before learning to read, children are able to interpret drawings and photographs autonomously, first in isolated ways, then recognizing relationships and successions or creating them, until they compose their own stories.

And this happens today more than ever, because in our time the iconographic and visual universe has a fundamental weight due in the first place to its speed of interpretation, fruition and consumption.

This is the context of the concrete experience analysed in this study. Given that kindergarten/under-five kids of today are growing up surrounded by images as never before and are acquiring an iconographic interpretation capacity probably superior to ours (just as we usually speak of "digital natives"), what would happen if pre-reading children were empowered by allowing them to be the architects of their own interpretation of the text, not already written, evidently, but iconic?

First of all, is this possible? There is a particular niche in the great world of children's books which in this sense can provide us with concrete help. This is the world, still, little known in the Hispanic world, of silent books, those illustrated albums where the image has absolute protagonism (often there is not even a trace of written text: see Bosch, 2012; Beckectt, 2012). According to Geisert's definition (1991), "wordless books are 'almost' wordless books that contain very minimal text, such as books with one word like Oink" (Jalongo et al., 2002, p. 167). In this sense, educational experiences related to this style of picture book have recently been carried out. One of the most interesting contributions is that of professor Evelyn Arizpe who, in her article Wordless Picture books: Critical and Educational Perspectives on Meaning-Making, includes several proposals such as that of 
Nodelman (1988) or Rowe (1996). All of them highlight the same fact: "the active participation expected of the implied reader" (Arizpe, 2014, 96). In any case, this research focuses on pre-readers, unlike other pioneering studies that analysed visual reading by primary school pupils (see Arizpe \& Styles, 2015).

Could pre-reading children "read" these "texts" autonomously? Would they be able to tell stories turning themselves into storytellers and mediators? And how would this eventual capacity help them tomorrow to become autonomous readers? Would this be reflected in an enrichment of the pre-reading parameters, the four cognitive precursors identified by the NRP?

\section{Methodology}

\section{Aim and objectives}

The general objective of our study is to observe if the use of the Silent Books can cause more active participation of the pre-reader students, both in the classroom and in their family context. For this reason, an intervention is carried out and analyzed by introducing the Silent Books in a kindergarten educational center. The specific objectives are the following:

- To discover if pre-readers can "read" silent books autonomously.

- To observe whether their capacity to be literary mediators in the family context and at school increases.

- To examine whether the intervention provides enrichment of pre-reading parameters, the four cognitive precursors identified by the NRP.

\section{Sample}

Data were obtained from a group of 27 children from a kindergarten in the capital city of Seville, aged 2-3. They all belong to the upper middle class and are the children of at least one professional parent.

\section{Intervention protocol}

First, the implementation protocol considered the following aspects:

Phase 1: Reading in the classroom

The reading phase in the classroom has been structured in two moments:

a) First, traditional readings were proposed, guided by a researcher, to observe the reading routines: students were free to participate and did so actively, but the dynamic was always structured from a written text from which no variations were made. 
b) Secondly, a series of silent books have been introduced into the classroom, chosen according to the subjects dealt with in the classroom and the interest aroused in the children. The chosen books were also characterised by a simple format with few sequences, since "meaningful experiences with simple texts are probably the most important influences in early literacy development" (Forman et al., 1993, 317).

The albums were:

All Around Bustletown: Spring, by Susanne Berner Rotraut

The Chicken Thief, by Béatrice Rodríguez

The Red Balloon, by Lela Mari

Yellow Umbrella, by Jae Soo Liu and Dong Il Sheen

I miss you, by Laura Espot

In order to guarantee an elicitation of a self-managed narration by a 2-3-year-old child, silent books were used, so that the adult did not have to mediate the reading. In other words, the album without words allows us to move away from guided literacy, even if it sometimes has words such as titles or credits (Bosch, 2012). In addition, books with an impacting visual grammar (Kress and Van Leeuwen, 2001) and with a clear sequential discourse were chosen.

\section{Phase 2: Reading at home}

In the next phase of the research, five children were selected as candidates to take a silent book to their home. The criteria used were:

- Significant changes in his/her reaction from the traditional group readings to the Silent Book one.

- Some kind of difficulty in expressing oneself that has been appeased by the use of this resource.

- A high degree of imagination in creating stories.

- Acceptance by families to actively participate in the intervention.

Once selected, a silent book was given to each family (the choice of silent book was mainly linked to the interest of the child). Along with the book, a letter to the parents was sent home, which included a series of steps to follow. The steps were:

1. The book should be left at children's disposal, that is to say, that they can take it and/or manipulate it whenever they want. This will be fundamental in order to observe what interest it arouses in the child and if he/she associates it to certain moments of the day.

2. It will be interesting if you first ask your child to tell you the story, so that you can see how he/she tells it and what attracts his/her attention the most, as well as being a great activity when it comes to stimulating language. 
3. In the end, on another day of the weekend or at another time, read him/her the story as you wish, and we will see what attitudes change and what things he/she continues to do as on the previous occasion.

Finally, families were asked to share their experience through audios and video recordings.

\section{Analysis criteria}

The methodological analysis was based on a qualitative, ethnographic approach (Angrosino, 2012; Gibbs, 2012). Below an exemplification of the procedure can be found (Figure 1):

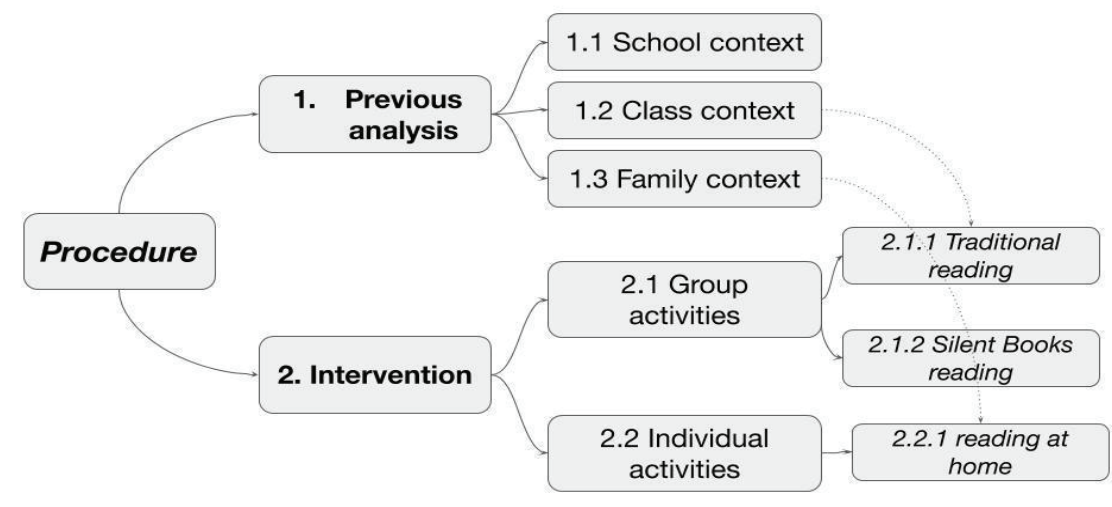

Figure 1. Scheme of the intervention

A study of the context has been carried out. This has involved three key moments: 1. An analysis of the centre's economic and socio-cultural environment.

2. An analysis of the classroom context. A direct observation of the materials used was made, examining the classroom library with special attention. Firstly, its book list was drawn up and analysed observing the interest that each text aroused in the students; subsequently, an interview with the 2-3-year-old classroom tutor was carried out, in order to know the class reading routines. After that, an analysis of the class group was carried out, through a direct observation of the environment (instrument used in this case were a field diary and audio recordings).

3. Family context. In addition to the data collected through the aforementioned interviews, family context has been analysed through a questionnaire with open and closed questions about their relationship with the neighbourhood, the daily routines shared with the children and a section referring to reading habits and the importance of reading at home. 
The analysis of the data is based on a theoretical and methodological approach of communicative multimodality (Kress \& Van Leeuwen, 2001) in New Literacies (Knobel \& Lankshear, 2007; Ehret \& Leander, 2018), using the verbal protocol technique. The verbal protocol technique is defined as

a methodological procedure used in research that offers qualitative information. The verbal protocol is a method that makes it possible to obtain individual accounts of one's own cognition during the execution of a task or as it is being remembered (De Brito, 2006).

This approach focuses on the different resources that the subject uses to narrate, affecting the semiotic potential of extraverbal strategies to give meaning to what is told. This is especially interesting considering that our study contemplates an age range in which subjects communicate mainly through gestures, images or sounds (Kress, 2010; Anstey \& Bull, 2010). Also, the analysis considered the classification of Sipe (2008) to categorize the responses of infants to reading picture books.

Likewise, when it comes to research in children's classrooms, qualitative methods are presented as a preferable alternative, since there is no better way to study a change, analyse behavior or deduce why there are different attitudes than by observing them closely. Infants of that age are in continuous interaction with their environment and others, and many of these interactions give clues about an enormous amount of study variables.

\section{Instrument}

The data collection carried out for this group has had different formats, in order to cover the different parts of the ethnographic study (Angrosino, 2012). According to the different contexts mentioned, the instruments are shown in the following table (Table 1).

Table 1

Analysis of resources

\begin{tabular}{lll}
\hline \multicolumn{1}{c}{ School context } & \multicolumn{1}{c}{ Class context } & \multicolumn{1}{c}{ Family context } \\
\hline - Study of official reports of the & - Teacher's Field Diary & - Questionnaire \\
public administration & & - Researcher's field diary \\
- Interview with the school & - Students' audio recordings & - Audio recordings \\
principal & & - Parent records \\
\hline
\end{tabular}




\section{Results and analysis}

\section{Literacy in the context of the centre}

The kindergarten where the intervention was carried out is in Seville downtown. It is a medium-high socio-economic level context, as seen when various variables are analysed (i.e. economic activity, housing cost and shopping facilities in the area).

During the interview, the school principal confirmed that the families' socioeconomic level is medium high, although she also underlines that many families of foreign origin live with the help of subsidies or have precarious jobs.

\section{Literacy in the classroom context}

By combining the transcriptions of the classroom readings with the notes from the observation diary, it has been possible to propose a first multimodal analysis (see Table 1). The importance of this type of analysis is revealed in the fact that the pre-reading infant approaches a text in which the image prevails.

As Guzmán Simón notes, "the logic of the image [...] implies a different reading from the strictly verbal one: here, the reader exercises a completely new autonomy choosing what really interests him/her" $(2015,36)$. This autonomy is what is going to be analysed: if, and how, a child can become autonomous in the "reading" of a "text" with no text.

On the one hand, for traditional readings, books from the class library were used. Giving the kids freedom to choose, the choice always fell on The Colour Monster (Llenas, 2012) or A Taste of the Moon (Grejniec, 2007). When they already knew the story, the children used to highlight the same images and, moreover, they preferred the text to be followed to the letter. No active attitude was shown by the children.

On the other hand, the Silent Books group readings followed a specific routine: the students were arranged in such a way that everyone had a good view of the story, since in this case it was essential that they were seeing the images. For the analysis, a series of tables were elaborated to describe these events, classifying the subjects who spoke with their verbal and nonverbal language. See the following example (Table 2).

During the readings, various linguistic and behavioural elements could be observed in the subjects, either repeatedly or univocally. It is remarkable that this form of reading has helped some children who presented clear signs of shyness to begin to participate more in the readings (Table 2: reading 1, block 2 line 36), coinciding with the conclusions of the investigations of Reynolds \& Evans (2008). In this case, N6 (a child labeled as especially shy by the tutor) jumps out of his place to indicate the image of a horse, after the intervention of another child who has verbally captured the image. 
Table 2

Excerpt from the multimodal analysis chart

\begin{tabular}{|c|c|c|c|c|}
\hline Block & Row & Transcription & Code 1 & Code 2 \\
\hline \multirow{17}{*}{$\begin{array}{l}2 \\
\text { (Story- } \\
\text { telling) }\end{array}$} & 27 & N16: ¡Qué asco! & \multirow{17}{*}{$\begin{array}{l}\text { N17 points to a dog and } \\
\text { calls it "guagua" } \\
\text { N10 points to the chick- } \\
\text { ens and says something } \\
\text { similar, but almost } \\
\text { without vocalizing } \\
\text { N6 does not usually } \\
\text { speak, possibly because } \\
\text { of shyness }\end{array}$} & \multirow{4}{*}{$\begin{array}{l}\text { He grimaces and } \\
\text { looks away }\end{array}$} \\
\hline & 28 & $\begin{array}{l}\text { Yo: ¿No te gustan los pájaros? } \\
\text { Son }\end{array}$ & & \\
\hline & 29 & $\begin{array}{l}\text { geniales porque salen en pri- } \\
\text { mavera y }\end{array}$ & & \\
\hline & 30 & cantan & & \\
\hline & 31 & N14: el camión & & \multirow{3}{*}{$\begin{array}{l}\text { He makes the sound } \\
\text { of a firetruck }\end{array}$} \\
\hline & 32 & $\begin{array}{l}\text { Yo: Y ahora, el camión sigue } \\
\text { andando }\end{array}$ & & \\
\hline & 33 & y llega a una granja. & & \\
\hline & 34 & N8: Una vaca. & & \multirow{6}{*}{$\begin{array}{l}\text { Everyone starts } \\
\text { pointing to things on } \\
\text { the pages especially } \\
\text { animals and a pond }\end{array}$} \\
\hline & 35 & N17: ¡Un caballo! & & \\
\hline & 36 & N6: ¡Caballo! & & \\
\hline & 37 & N8: Mira, un pato & & \\
\hline & 38 & Yo: ¿Y esto qué es? & & \\
\hline & 39 & N16: Un gato & & \\
\hline & 40 & $\begin{array}{l}\text { Yo: Un gato, muy bien... y } \\
\text { están todos }\end{array}$ & & \multirow{4}{*}{$\begin{array}{l}\text { N6 gets excited and } \\
\text { jumps out of his seat } \\
\text { to point at the horse }\end{array}$} \\
\hline & 41 & $\begin{array}{l}\text { muy contentos porque es } \\
\text { primavera, } y\end{array}$ & & \\
\hline & 42 & $\begin{array}{l}\text { ya hay buen tiempo y todos } \\
\text { salen de sus casas, }\end{array}$ & & \\
\hline & 43 & y mira, aquí ¿Qué hay? & & \\
\hline
\end{tabular}

It is a type of response based on kinesthetic language, but in this case, it is parallel to the intervention of another child.

On the other hand, it has been observed on different occasions the identification of the pre-readers with the characters, recalling their own experiences (reading 5, block 2, line 87), with a clear intention of connecting with the aspect of their own life, "text-tolife" (Sipe, 2008). Even from a multimodal perspective, it can be observed how one of the children makes a disgusting gesture and looks away when the teacher shows the birds, thus personalizing the story to his own preference (Table 2).

Quite often, during the story telling, "small debates" arose among the subjects that provoke the adoption of a vocabulary that they do not usually use (they try to discover the specific name of the concepts to which the images allude). This promotes the acquisition of vocabulary and an improvement in language skills (reading 3, block 2, line 65). They use "intertextual" answers (Sipe, 2008), since they establish associative networks, "This is like...", leading to conclusions on the meaning of those words. In this case, there are even children who learn new words or, at least, to say them aloud, as a result of repetition and 
appearance in the story, due to the need to intervene in this new type of participatory reading (reading 3 , block 2 , line 116 ).

In addition, in this silent book reading, the change in the children's body posture is relevant: they stand on the chair to see the images better, they clap their hands, they stand up to point to the image. The interpersonal deixis also increases (the use of the vocative of the teacher's own name, seeking an effect of solidarity) to glimpse the general motivation towards the album.

\section{Literacy in the family context}

As far as the data from the questionnaire are concerned, it is noteworthy that $100 \%$ of the parents responded that the children have total access to books at home. However, as regards the number of books they read (themselves) per year, $76 \%$ answered that they read $0-6$ books, with a percentage of $10 \%$ acknowledging that they do not read any books at all. Going deeper into the last part of the application protocol, in which the family shared the experience of their children telling the silent book worked in class, some interesting patterns can be observed:

- Growing motivation towards the book as an object

The parents themselves relate that the activity of mediated reading in which the child is the protagonist produces a greater motivation for them towards the moment of reading, and generates a process of active listening: "the truth is that the experience was good, I liked it quite a lot because I had never seen a story like this (...) because he, well, because he has got into the story and has been telling his things" (N1). Another of the key aspects observed both in the parents' stories and in the recordings of the children's narrations is the importance of the protagonism of the child as a narrating agent. Every time the parents take the mediation role back, the reaction of the children is unequivocal: they want to be the narrators again, "they got angry if I didn't point and tell what they wanted and they also wanted to interrupt me all the time" (N3).

The increase in references to personal life is also interesting: students seem to "project (Gombrich, 1979) in the book their experiences (...), read their own history" (Fittipaldi, $2012,76)$. For example, in this case, in order to access this personal reading of "text-tolife" and "life-to-text" both paths are shown: "(pointing to the image of a block of flats) to the bathroom, to the bathroom you cannot go by yourself, and so, here there is a TV, here another TV, on that TV you can watch Charlie (a cartoon he watches at home)" (N4). In other words, an identification is created with each of the images: the subject uses the illustrations as a trigger for events inspired by his daily reality, and vice versa (Sipe, 2008). It is logical that this happens at home, where there are greater affective bond and a more relaxed context than in school, but it also gives a key to a generalized approach to the phenomenon of reading for these 2-3-year-old children. 


\section{- Cognitive precursors}

The approach of all children to narration follows the tradition of the grammar of stories exposition (Stein and Glenn, 1979). In fact, in some cases where books have a narrative structure that is more difficult to perceive - due to a preponderance of metaphorical images -, students invent a traditional structure to give meaning to the book.

There is also an increase in vocabulary at home compared to the infant's response in the classroom (Reading 5, N8 uses "prison" when pointing to the kennel). Another interesting factor is the children's ability to verbalize the power of the images, how they manage to transform iconographic performativity into literalness: "The baby and his father are happy, the father is saying wait wait (he raises his hand the same as the father, moving his head towards the parents, he clarifies), the father says wait wait with the hand" (N6). In addition, through interpersonal deixis and the use of rhetorical interrogation, they interact with parents to reaffirm their authority as narrators: "The father is scolding the dog, he is putting the leash on it so that it does not run, see? I told you (when he sees the child pulling the leash of the dog)" (N6). The parents also highlight the manipulation of the picture book as an object and children's confident approach to it.

\section{Discussion and conclusions}

In many cases, research about pre-reading children's family environment has tried to discover how to carry out reading mediations starting from the role of the mother (Melzi \& Caspe, 2005; White \& Low, 2002; DeBaryshe et al., 2000), or to analyse initial literacy according to the type of family (De-La-Peña, Parra-Bolaños, \& Fernández-Medina, 2018; Moreno, 2013). This research, however, shows how the motivation to approach any area of literacy depends not only on families and schools, but also on the type of events that occur to encourage this habit or reading exercise in pre-reading children (Lankshear \& Knobel, 2007).

Reading and writing should be seen as the last link in a long chain that starts from the first interactions with the written text, regardless of the medium and the official channel. After evaluating this experience, one should ask what influences the pre-reading child to grow an interest in the text. The analysis concludes that there is a need for an affective relationship (Ehret \& Leander, 2018), but not necessarily the need for a direct reading interpretation by those who already dominate the code. In fact, silent books, unlike traditional books, emerge in this pre-reading context as a powerful tool since early childhood, because the "reader", the main actor in the interpretation of the code, may well be the child himself as he/she responds to an iconographic reading (Follmer \& Semb, 2007).

In addition, during the group reading it can be observed how silent books induce an oral, subjective and changing experience, motivated by the discussion generated around the interpretation of the book (Reynolds \& Evans, 2008). Another interesting issue is 
the constant allusion to children's own reality when they become narrators since they construct meaning from the identity they develop in their daily social practice and use it to interpret the text (Pahl \& Rowsell, 2012). In addition, the use of silent books expands their social imagination, an essential skill for establishing and maintaining relationships with others (Lysaker \& Miller, 2013).

One might, therefore, ask if children can be empowered through silent books.: what happens if the infant becomes an interpreter of the text? From the historical point of view, we can glimpse an ethical change in the teaching of writing and reading due to the "emergence of new socialites" (Caballero, 2009) linked to digital practices: we do not read or write the same way we did some decades ago, therefore we should not teach and learn it in the same way. Hence, new tools to help us measure the true impact of these changes on literacy processes must be developed. This research tries to analyse how the appropriation of "textual" discourse by children, thanks to the absence of this in silent books, generates narrative empowerment. The concept of literacy, from this point of view, opens up to a broader sense since it is inserted in practices that allow the subject to "decode" the messages in order to extract the information from them and thus be able to form their own knowledge (Area et al., 2012).

In this sense, with this pre-reading practice, children transform the concept of literacy completely through the visual element (Bearne \& Wolstencroft, 2007), guaranteeing it a more participative, collaborative, democratic nature, typical of this digital era both in its use and in the way it is shared (Knobel \& Lankshear, 2007). Of course, these readings still cohabit with more conventional and rigid literacy practices supported and disseminated by the school (i.e.a traditional book), but they also open the door to discussing the need for infants to be prepared for a changing, complex society, where identity takes on a leading role.

As Lemke said, "Online communities and social networks are not merely sites for exchanges of information. They are also sites for experimentation with identities" (2009, 590); these endow "sense of including multiple social voices, giving the reader access to a field of heteroglossia, of discourse diversity and conflict" (Lemke, 2003, 323). If we put this in relation to literacy processes, we realise that the experimentation of identity takes place in the school in a very limited way, while in the informal literacy processes, thanks to the enlargement of the digital worlds, we do find heteroglossia and diversity, both so necessary for the acceptance and legitimisation of multiplicity of identities.

In this sense, the New Literacy Studies arise as a need to frame literacy as a social and educational practice (Lankshear \& Knobel, 2011), beyond the psycholinguistic or structuralist analysis that has predominated in the study of linguistic and literary competence so far. The results of this research show that the shared cultural reference, the affective bond with the narrator (Quintanal, 1999), the use of artistic languages (visual, sonorous, kinesthetic) through the picture book and the manipulation of it as a "discursive strategy" (Tabernero-Sala, 2018, 75) can help pre-reader subjects to take centre stage in this literacy exercise, as further research on literacy in the field of inclusion underlined (Bolos, 
Fuentes-Peláez \& Pastor, 2017; Haquin, Cornejo \& Arancibia, 2016; Acosta, Moreno \& Axpe, 2011; Aram, Most \& Mayafit, 2006). Therefore, this study highlights the convenience and the need to explore the relationship between Silent Books and initial literacy, with a methodology based on dialogical readings and infant self-managed narration, in order to begin to provide students from early childhood with powerful tools to coexist in the society of the twenty-first century. As Arizpe and Styles emphasize "picturebooks offer something no other medium can quite match" (2015, xvii).

\section{Funding}

This study was developed within the frame of the National R\&D Apertura Project "Literacy as a social practice in Infant and Primary Education (5-7 years): Research and design of intervention in children at risk of social exclusion in urban contexts", financed by the Ministry of Economy, Industry and Competitiveness of Spain (Excellence Plan 2018-2020, code EDU2017-83967-P).

\section{References}

Acosta, V., Moreno, A., \& Axpe, A. (2011). Analysing Oral Language and Early Literacy Practices in Pupils with Specific Language Impairment in Family and Classroom Contexts. [Análisis de las prácticas de lenguaje oral y de lectura inicial en escolares con trastorno Específico del Lenguaje en contextos de familia y aula] Cultura y Educación, 23(1), 43-56. Retrieved from: https://doi.org/10.1174/113564011794728579

Angrosino, M. (2012). Etnografía y observación participante en investigación cualitativa. Morata. Aram, D., Most, T., \& Mayafit, H. (2006). Contributions of Mother-child Storybook Telling and Joint Writing to Literacy Development in Kindergartners with Hearing Loss. Language, Speech, and Hearing Services in Schools, 37, 3, 209-223.

Área, M., Gutiérrez, A., \& Vidal, F. (2012). Alfabetización digital y competencias informacionales. Barcelona: Ariel.

Area, M., \& Pessoa, T. (2012). From Solid to Liquid: New Literacies to the Cultural Changes of Web 2.0. Comunicar, 19(38), 13-20. Retrieved from: http://doi.org/10.3916/C38-2012-02-01 Arizpe, E. (2014). Wordless Picturebooks: Critical and Educational Perspectives on Meaningmaking. In Picturebooks: Representation and Narration (pp. 109-124). Routledge.

Arizpe, E., \& Styles, M. (2015). Children Reading Pictures. Interpreting Visual Texts. Routledge: Falmer. Balbi, A., von Hagen, A., Cuadro, A., \& Ruiz, C. (2018). Revisión sistemática sobre intervenciones en alfabetización temprana: implicancias para intervenir en español. Revista Latinoamericana de Psicología, 50(1), 31-48. Retrieved from: https://dx.doi.org/10.14349/rlp.2018.v50.n1.4

Bauman, S. (2003). Comunidad. En busca de seguridad en un mundo hostil. Madrid: Siglo XXI. 
Bearne, E., \& Wolstencroft, H. (2007). Visual Approaches to Teaching Writing. London: UKLA/ Paul Chapman Publishing. Retrieved from: http://dx.doi.org/10.4135/9781446214398 Beckett, S. L. (2012). Crossover Picturebooks. A Genre for All Ages. New York: Routledge. Bolós, A. M., Fuentes-Peláez, N., \& Pastor, C. (2017). El fomento de la inclusión social infantil a través de los lenguajes artísticos. Pedagogía social: revista interuniversitaria, 29, 143-156.

Bosch Andreu, E. (2012). ¿Cuántas palabras puede tener un álbum sin palabras? Ocnos: Revista de estudios sobre lectura, 0(8), 75-88. Retrieved from: https://doi.org/10.18239/ocnos_2012.08.07 Bull, G. \& Anstey, M. (2010). Evolving Pedagogies: Reading and Writing in a Multimodal World. Carlton South: Education Services Australia.

Burnett, C., Merchant, G., Pahl, K. \& Rowsell, J. (2014). The (Im)materiality of Literacy: the Significance of Subjectivity to New Literacies Research. Discourse: Studies in the Cultural Politics of Education, 35 (1), 90-103. Retrieved from: https://doi.org/10.1080/01596306.2012.739469

Caballero, S. L. (2009). Tránsito digital en el ámbito educativo. Revista Iberoamericana de Educación, 6(48), 1-13.

De-La-Peña, C., Parra-Bolaños, N., \& Fernández-Medina, J. (2018). Analysis of Initial Literacy Depending on the Type of Family. [Análisis de la alfabetización inicial en función del tipo de familia]. Ocnos: Revista de estudios sobre lectura, 17(1), 7-20. Retrieved from: https://doi. org/10.18239/ocnos_2018.17.1.1336

De Brito Neves, D. A. (2006). La verbalización como registro para análisis en la investigación sobre lectura. In Anales de documentación, 9 (pp. 43-51). Facultad de Comunicación y Documentación y Servicio de Publicaciones de la Universidad de Murcia.

De Baryshe, B. D., Binder, J. C., \& Buell, M. J. (2000). Mothers' Implicit Theories of Early Literacy Instruction: Implications for Children's Reading and Writing. Early Child Development and Care, 160(1), 119-131.

Durán, T. (2002). Leer antes de leer. Madrid: Anaya.

Follmer Greenhoot, A., \& Semb, P. (2008). Do Illustrations Enhance Preschoolers' Memories for Stories? Age-related Change in the Picture Facilitation Effect. Journal of Experimental Child Psychology, 99(4), 271-287. Retrieved from: https://doi.org/10.1016/j.jecp.2007.06.005

Forman, E. A., Minick, N., \& Stone, C. A. (Eds.). (1993). Contexts for Learning: Sociocultural Dynamics in Children's Development. New York: Oxford University Press.

Gibbs, G. (2012). El análisis de datos cualitativos en investigación cualitativa. Ediciones Morata. Guzmán-Simón, F. (2015). Alfabetización Multimodal. In E. Martos Nuñez \& M. Campos Fernández-

Fígares, Diccionario de nuevas formas de lectura y escritura (pp. 36-40). Madrid: Santillana.

Haquin, D. M., Otárola Cornejo, F., \& Arancibia M. (2016). Adaptaciones metodológicas para el análisis del discurso de niños con discapacidad intelectual: narrando sin lenguaje. Signo y Pensamiento, 35(69), 68-82. Retrieved from: https://dx.doi.org/10.11144/Javeriana.syp35-69.amad Jalongo, M. R., Dragich, D., Conrad, N. K. et al. (2002). Using Wordless Picture Books to Support Emergent Literacy. Early Childhood Education Journal, 29 (3), 167-177. Retrieved from: https:// doi.org/10.1023/A:1014584509011

Knobel, M., \& Lankshear, C. (2007). A New Literacies Sampler. Peter Lang. 
Knobel, M., \& Lankshear, C. (2012). Literacies: Social, Cultural and Historical Perspectives. In Peter Lang. Kress, G. \& van Leeuwen, T. (2001). Multimodal Discourse: The Modes and Media of Contemporary Communication. London: Arnold.

Kress, G. (2010). Multimodality: A Social Semiotic Approach to Contemporary Communication. Abingdon: Routledge.

Leander, K. M., \& Ehret, C. (2019). Affect in Literacy Learning and Teaching: Pedagogies, Politics and Coming to Know. New York: Routledge.

Lemke, J. L. (2002). Travels in Hypermodality. Visual Communication, 1(3), 299-325. Retrieved from: https://doi.org/10.1177/147035720200100303

Lemke, J. (2009). Transmedia Traversals: Marketing Meaning and Identity. In A. Baldry and E. Montagna (eds.), Interdisciplinary Perspectives on Multimodality: Theory and Practice. Proceedings of the Third International Conference on Multimodality (pp. 576-596). Campobasso: Palladino.

Lysaker, J. T., \& Miller, A. (2013). Engaging Social Imagination: The Developmental Work of Wordless Book Reading. Journal of Early Childhood Literacy, 13(2), 147-174.

Martos García, A. (2013). Alfabetización plural. In E. Martos Núñez. \& M. Campos FernándezFígares (Eds.), Diccionario de nuevas formas de lectura y escritura (pp. 32-35). Madrid: Santillana. Moreno Sánchez, E. (2013). Análisis de la influencia de la familia en los hábitos lectores de sus hijas e hijos: un estudio etnográfico. Contextos Educativos. Revista de Educación, 4, 177-196.

Neuman, S. B., \& Dickinson, D. (eds.) (2011). Handbook of Early Literacy Research. New York: Guilford Press.

Nodelman, P. (1988). Words about Pictures: The Narrative Art of Children's Picture Books. Georgia: University of Georgia Press.

Quintanal, J. (1999). Lectura de regazo, más que un derecho una necesidad. Madrid: Dykinson.

Pahl, K., \& Rowsell, J. (2012). Literacy and Identity: Who are the Meaning Makers? In K. Pahl. \& J. Rowsell (Eds.), Literacy and Education (pp. 111-136). London: SAGE Publication Ltd.

Reynolds, K., \& Evans, M. (2009). Narrative Performance and Parental Scaffolding of Shy and Nonshy Children. Applied Psycholinguistics, 30(2), 363-384. Retrieved from: https://doi. org/10.1017/S0142716409090158

Rowe, A. (1996). Reading Wordless Picture Books. In M. Styles, E. Bearne \& V. Watson (Eds.). (1996). Voices off (pp. 219-234). London: Cassell.

Sanjuán Álvarez, M. (2013). La dimensión emocional del aprendizaje literario. In M. Sanjuán Álvarez (ed). La dimensión emocional en la educación literaria (pp. 80-215). Zaragoza: Prensas de la Universidad de Zaragoza.

Sipe, L. (2008). Storytime: Young Children's Literary Understanding in the Classroom. Teachers College Press.

Soler, M. (2003). Lectura dialógica. La comunidad como entorno alfabetizador. In A. Teberosky \& M. Soler (eds.). Contextos de alfabetización inicial (pp. 47-63). Barcelona: Horsori.

Solé, I. (2009). Motivación y lectura. Aula de innovación educativa, 179, 56-59.

Tabernero-Sala, R. (2018). Arte y oficio de leer obras infantiles. Barcelona: Octaedro. 
Vivas Moreno, A., \& Martos García, A. (2013). Cultura letrada y cibercultura. In E. Martos Núñez. \& M. Campos Fernández-Fígares (Eds.), Diccionario de nuevas formas de lectura y escritura (pp. 160-164). Madrid: Santillana.

White, S., \& Low, J. (2002) When Mothers Turn a Visual Story into a Verbal One For Their Children: Previewing Helps With the Telling, Conversing, and Remembering, International Journal of Behavioral Development, 26(4), 360-370. Retrieved from: https://doi. org/10.1080/01650250143000256

\title{
Leisk man papasakoti tau: „tylių knygu““ patirtis ankstyvojo raštingumo kontekste
}

\author{
Elena Guichot-Muñoz ${ }^{1}$, Giulia De Sarlo², Elena Ledesma-Gobea ${ }^{3}$ \\ Sevilijos universitetas, Kalbų ugdymo katedra, C/ Pirotecnia s/n, ES-41018 Sevilija, Ispanija, eguichot1@us.es \\ Sevilijos universitetas, Kalbų ugdymo katedra, C/ Pirotecnia s/n, ES-41018 Sevilija, Ispanija, gdesarlo@us.es \\ Sevilijos universitetas, Edukologijos fakultetas, C/ Pirotecnia s/n, ES-41018 Sevilija, Ispanija, elenalg96@gmail.com
}

\section{Santrauka}

Ankstyvasis raštingumas yra vienas iš svarbiausių kalbos ịgūžių ugdymo ankstyvojoje vaikystejje tyrimų aspektų. Šiame straipsnyje daugiausia demesio skiriama vaikų skaitymo motyvacijai mokykloje ir šeimoje bei „tylių knygų“ (angl. Silent Books) - paveikslèlių knygų be teksto - eksperimentui, kuris buvo atliktas su 27 darželio vaikais iš Sevilijos (Ispanija). Taikydami kokybinę etnografijos metodologiją, paremtą multimodaline analize (Kress \& Van Leeuwen, 2001), mes nagrinėjame grupei, sudarytai iš penkių mokinių, duotų „tylių knygų“ savarankišką skaitymą klasėje ir namuose. Pagrindinis tyrimo tikslas yra stebėti, ar „tylių knygų“ naudojimas gali paskatinti aktyvesnị vaikų dalyvavimą tiek klasẻje, tiek jų šeimoje. Dèl šios priežasties tyrimas vykdomas ir analizuojami jo rezultatai pristatant „tylias knygas“ darželio ugdymo centre.

Tyrimo rezultatų analizė atskleidžia ne tik staigų motyvacijos ị knygą, kaip objektą, padidejjimą, bet taip pat daugelio kognityvinių funkcijų, susijusių su ypatingu dèmesiu žodinei kalbos plètrai, suaktyvejjimą.

Mūsų tyrimo išvados rodo poreikị skatinti savarankišką ikonografinị skaitymą kūdikiams, kaip skaitymo veiksmą ir kaip veiksmingą ịrankị susiduriant su naujomis XXI amžiaus rašymo bei skaitymo formomis.

Esminiai žodžiai: ankstyvoji vaikystè, raštingumas, tylios knygos, savarankiškas skaitymas, kokybinis tyrimas.

Gauta 20191202 / Received 02122019

Priimta 20200309 / Accepted 09032020 